\title{
Production of calcium- and magnesium-enriched caseins and caseinates by an ecofriendly technology
}

\author{
Félix-André Masson, ${ }^{*} \dagger$ Sergey Mikhaylin, ${ }^{*} \dagger$ and Laurent Bazinet ${ }^{*} \dagger^{1}$ \\ *Institute of Nutrition and Functional Foods, Dairy Research Center (STELA) and Department of Food Sciences, and \\ †Laboratoire de Transformation Alimentaire et Procédés ElectroMembranaires (LTAPEM, Laboratory of Food Processing \\ and ElectroMembrane Processes), Université Laval, Québec, QC, Canada G1V0A6
}

\begin{abstract}
Finding new environmentally friendly ways of producing proteins has never been of such critical public interest, both to meet consumers' needs and to preserve the environment. Milk proteins are among the most attractive protein types due to their high nutritional value and attractive functional properties. In this work, the separation of caseins by conventional chemical acidification was compared with electrodialysis with bipolar membrane coupled to an ultrafiltration module (EDBM-UF), a green process that allows the precipitation of caseins by $\mathrm{H}^{+}$generated in situ by the bipolar membrane and, simultaneously, the production of a separated $\mathrm{NaOH}$ stream from $\mathrm{OH}^{-}$electrogenerated by the bipolar membrane. Caseinate production using this $\mathrm{NaOH}$ stream by-product and the quantity of $\mathrm{NaOH}$ needed to produce caseinates from both methods were also investigated. Hence, the purity and composition of caseins and caseinates were compared in terms of protein, ash, and lactose contents as well as mineral composition. The results showed for the first time that caseinates can be produced by solubilizing caseins with $\mathrm{NaOH}$ stream from the EDBM process. Furthermore, the caseins and caseinates produced by EDBM-UF were equivalent in terms of lactose and protein contents to their respective caseins and caseinates that were chemically produced but presented slightly lower sodium content and 3 to 4 times higher magnesium and calcium contents. The fact that calcium and magnesium are likely bound to milk caseins would ensure their favorable absorbability. These caseins or caseinates from the new EDBM-UF process could be suitable as an improved protein-based calcium or magnesium supplement, both for their enhanced nutritional quality and because they are produced by a "green" process.
\end{abstract}

Received October 17, 2017.

Accepted April 2, 2018.

${ }^{1}$ Corresponding author: Laurent.Bazinet@fsaa.ulaval.ca
Key words: caseins, caseinates, bipolar membrane electrodialysis, ultrafiltration, calcium-enriched ingredients

\section{INTRODUCTION}

With the growing world population, demand for highquality protein sources has been increasing steadily. However, the increasing demand in protein production is usually associated with environmental issues (Cao and Li, 2013). Finding new environmentally friendly ("green") ways of producing proteins has never been of such critical public interest, both to meet consumers' needs and to preserve the environment. Milk proteins are among the most attractive protein types because they have high nitrogen content and quality, promoting muscle synthesis (Elliot et al., 2006); contain various bioactive peptides, which aid in glycemic control and cardiovascular health (Korhonen and Pihlanto, 2006); and boast high levels of calcium, known to increase bone health and aid in preventing osteoporosis (Heaney, 2000; Thorpe et al., 2008). Caseins are 1 of the 2 major protein sources derived from milk, and their use as a functional ingredient (e.g., in the form of sodium caseinates) has been increasing steadily in recent years (MarketsandMarkets, 2014). Their most common manufacturing method necessitates the use of chemicals in the form of strong acids to achieve effective separation from milk. Indeed, separation of caseins from whey is most commonly achieved by reducing milk $\mathrm{pH}$ to its isoelectric point of 4.6 by acid addition, rendering them insoluble (Carr and Golding, 2016). Other methods of casein isolation include the addition of rennet to skim milk, leading to the precipitation of para-k-casein and casein macropeptides, and microfiltration and diafiltration, leading to the isolation of micellar casein (or phosphocasein; Carr and Golding, 2016). However, the composition and functional properties of rennet and micellar caseins differ from those of acid casein and caseinate (Mounsey et al., 2005; Augustin et al., 2011).

Nevertheless, a green process, electrodialysis with bipolar membrane (EDBM), can be used to isolate caseins from milk without the use of chemicals and to 
reduce production of effluents. This process uses anion exchange membranes and cation exchange membranes (CEM) to segregate the migration of ions through the cell and bipolar membranes (BPM) to produce $\mathrm{H}^{+}$ and $\mathrm{OH}^{-}$ions when an electrical current is applied. To reduce the $\mathrm{pH}$ of the milk, the $\mathrm{H}^{+}$ions electrogenerated by BPM are used (Bazinet et al., 1999; Tanaka, 2010). Another interesting advantage of this process is that a $\mathrm{pH}$ of 5.0 is sufficient to precipitate caseins efficiently (Mikhaylin et al., 2016a). Indeed, milk demineralization during the process reduces its ionic strength, facilitating the destabilization of the casein micelles, inducing their precipitation (Bazinet et al., 2000b); this is in contrast with the chemical process in which ions are added, increasing the ionic strength and decreasing the isoelectric point (Bazinet et al., 2000b). However, a major problem of this process is the fouling of the spacers by precipitated caseins during the electroacidification of milk (Bazinet et al., 1999) and mineral scaling (Bazinet et al., 2001). To avoid protein fouling, a UF module was recently coupled to the EDBM cell. This approach allows only the small components of milk (essentially water minerals and lactose) to be recirculated in the EDBM cell (Mikhaylin et al., 2016). In fact, the UF permeate (referred to as the MUF in this work) is acidified by the BPM of the EDBM stack and is recirculated in the UF module to reduce the $\mathrm{pH}$ inducing casein precipitation. Concerning scaling of membranes, Mikhaylin et al. (2018) proposed a new configuration of the EDBM cell to avoid scaling by separating the mineral concentrate compartment from the basification compartment of the EDBM stack.

However, in all previous studies on electrochemical acidification of caseins, the use of the base produced in parallel during the process has never been tested and evaluated in terms of composition of the final caseinates. Indeed, the final caseins obtained after acidification of milk can be used as caseins (insoluble) or can be further transformed into caseinates (soluble) with the addition of a base. These caseinates have interesting characteristics - namely, highly enhanced solubility in water compared with casein as well as increased foaming and emulsifying capacity (Singh, 2011) - making them a polyvalent functional ingredient with uses ranging from meat emulsifier to dairy foaming agent (Huffman and Harper, 1999). This ingredient has intriguing functional properties and possesses the nutritional qualities shared by all milk proteins products, making it a doubly interesting choice as a food ingredient.

In this work, the separation of caseins by the standard chemical acidification is compared with the green EDBM-UF process. Because the EDBM-UF process also produces (in parallel and in a separate compart- ment) an $\mathrm{NaOH}$ stream from $\mathrm{OH}^{-}$generated by the BPM, caseinate production using this recycled byproduct and the quantity of $\mathrm{NaOH}$ needed to produce said caseinates from both methods are investigated. The purity and composition of caseins and caseinates are compared by analyzing their protein, ash, and lactose contents as well as mineral composition to investigate the advantages of the EDBM method over the chemical process.

\section{MATERIALS AND METHODS}

\section{Materials}

The milk used in this study was a pasteurized skim milk (Pur Filtre; Parmalat, Toronto, ON, Canada). The $\mathrm{NaCl}$ (American Chemical Society grade) used for the electrolyte solutions was bought from BDH Chemicals (Radnor, PA). The $\mathrm{NaOH}, \mathrm{HCl}$, and $\mathrm{HNO}_{3}$ were purchased from Anachemia Canada Inc. (Montreal, QC, Canada).

\section{Electroacidification Cell}

The EDBM module (Figure 1) used was a laboratory scale cell (model MP; $100 \mathrm{~cm}^{2}$ of effective surface) from ElectroCell Systems AB Co. (Täby, Sweden). The cell comprised 6 compartments separated by 3 Neosepta CMX-SB CEM, 1 Neosepta AMX-SB anion exchange membrane, and 1 Neosepta BP-1 BPM (all membranes were food grade and produced by Astom, Tokyo, Japan; Figure 1). The anode, a dimensionally stable electrode, and the cathode, a 316 stainless steel electrode, were supplied with the MP cell. A UF module (filtration model L; GEA Process Engineering, Bönen, Germany) was coupled to the EDBM cell to allow only the mineral fraction of milk (MUF) to flow through the EDBM system and to avoid protein fouling of the spacers and ion-exchange membranes (Figure 1). The UF membrane used was a spiral-wound membrane of $2.14 \mathrm{~m}^{2}$ filtration area with a $10-\mathrm{kDa}$ molecular weight cut-off. The pressure used in the UF module during experiments was $30 \mathrm{psi}(207 \mathrm{kPa})$. The volume of milk treated in the UF module was $3 \mathrm{~L}$. The volumes treated in the EDBM cell were $500 \mathrm{~mL}$ of MUF, $700 \mathrm{~mL}$ of a $30 \mathrm{~g} / \mathrm{L} \mathrm{NaCl}$ solution, and $500 \mathrm{~mL}$ of a $2 \mathrm{~g} / \mathrm{L} \mathrm{NaCl}$ solution. The flow rates in the EDBM system were 600 $\mathrm{mL} / \mathrm{min}$ for the $30 \mathrm{~g} / \mathrm{L} \mathrm{NaCl}$ solution and $200 \mathrm{~mL} / \mathrm{min}$ for the $2 \mathrm{~g} / \mathrm{L} \mathrm{NaCl}$ solution. The flow rate of the MUF was changed during the experiments to keep a minimal volume of permeate circulating in the EDBM module between 400 and $500 \mathrm{~mL}$ (Mikhaylin et al., 2018). 
In this configuration, the $30 \mathrm{~g} / \mathrm{L} \mathrm{NaCl}$ solution (compartments 1, 5, and 6) was demineralized throughout the process, the sodium ions being attracted by the cathode and thus migrating from the first compartment through the CEM 1 to the second compartment. This solution is also demineralized by passing through the fifth compartment and the chloride ions going through the anion exchange membranes, being attracted by the anode. Therefore, this solution is doubly demineralized. This explains the choice of a $30 \mathrm{~g} / \mathrm{L}$ concentration for this solution of $\mathrm{NaCl}$; a lower concentration could have been too demineralized when approaching the end of the process and thus would have increased the system global resistance. At the same time, the $2 \mathrm{~g} / \mathrm{L} \mathrm{NaCl}$ solution (compartment 2) was supplied in $\mathrm{Na}^{+}$ions from the first compartment and in $\mathrm{OH}^{-}$ions electrogenerated by the BPM, consequently resulting in $\mathrm{NaOH}$. This $\mathrm{NaOH}$ was used for the production of caseinates later in the process. The MUF, being the UF permeate of milk, was recirculated in the third compartment of the EDBM, where it was acidified by $\mathrm{H}^{+}$produced by the BPM. The MUF is also demineralized by the migration of cations through the CEM 2 to the fourth compartment. The $2 \mathrm{~g} / \mathrm{L} \mathrm{NaCl}$ solution was concentrated in minerals by the migration of cations from the MUF and by the migration of $\mathrm{Cl}^{-}$from the $30 \mathrm{~g} / \mathrm{L}$ solution.
The first and sixth compartments were also used as electrode washing compartments.

\section{Protocol}

A 2.00-A current was kept constant for EDBM during the experiment. Conductivity in compartments 1 (to check ion concentration; a too-low concentration risked producing a water hydrolysis problem) and 4 (to check demineralization rate of MUF and consequently milk) were recorded throughout the process. The $\mathrm{pH}$ was measured in the UF retentate reservoir containing milk (to check milk acidification rate) and in compartments 2 (to check $\mathrm{NaOH}$ production) and 4 (to verify that $\mathrm{pH}$ did not become too basic, which would have put the membranes at risk of scaling problems; Mikhaylin and Sion, 2016) throughout the process. Conductivity and $\mathrm{pH}$ measurements were recorded at the beginning of the experiment, after 5 and $10 \mathrm{~min}$, and then every $10 \mathrm{~min}$ until the milk $\mathrm{pH}$ decreased to 4.8. Milk samples were taken in the UF retentate reservoir at the beginning of the experiment, at $\mathrm{pH} 6.2$, and then after each successive 0.4 decrease of $\mathrm{pH}$ up to the end of the treatment. Conductivity measurement of milk was carried out at the same intervals. Two liters of acidified milk was collected at the end of the experiment for centrifugation to

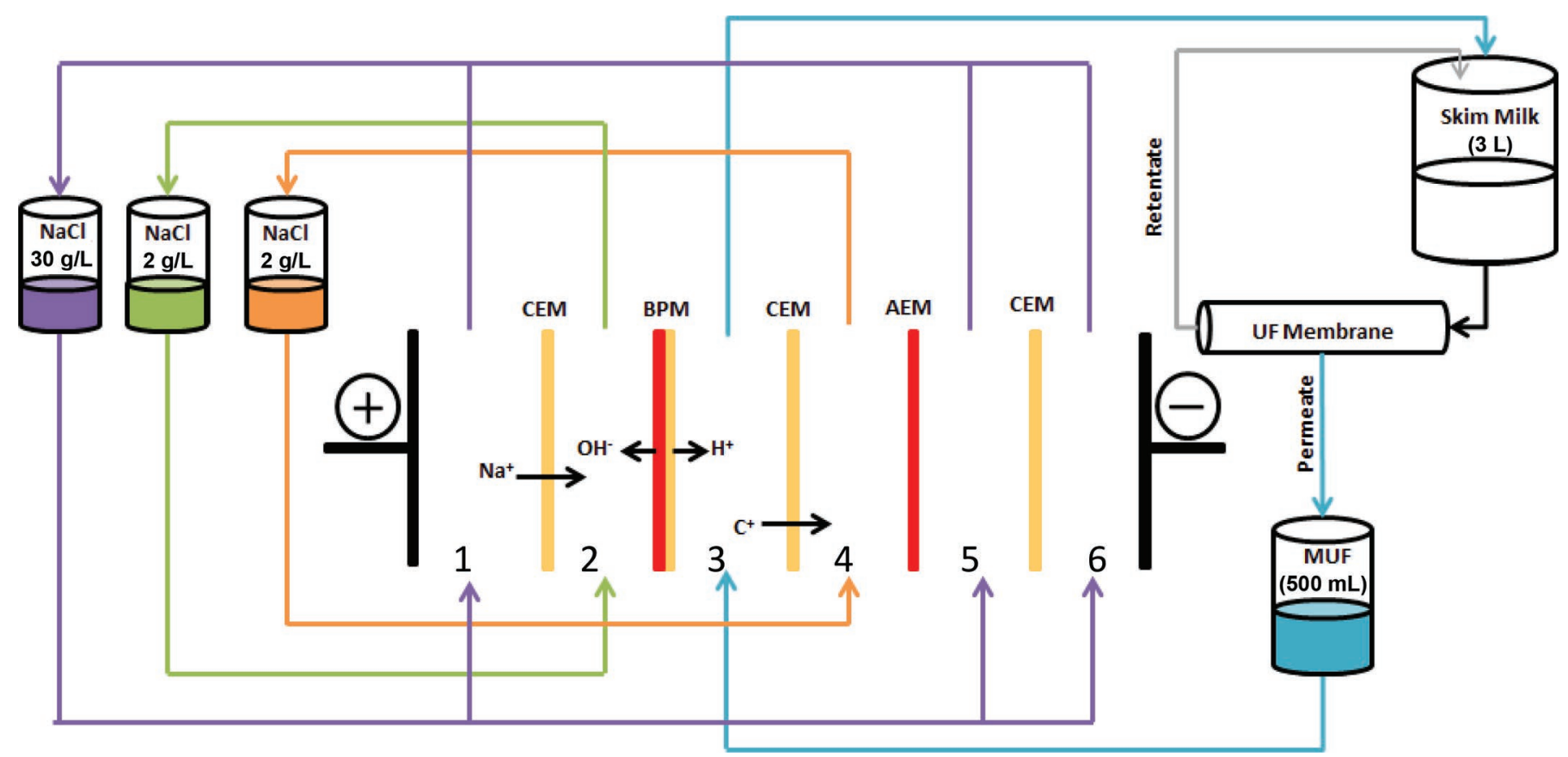

Figure 1. Configuration of the electrodialysis with bipolar membrane coupled to a UF module (EDBM-UF) system. $\mathrm{C}^{+}$are migrating cations. $\mathrm{CEM}=$ cation exchange membrane; $\mathrm{BPM}=$ bipolar membrane; $\mathrm{AEM}=$ anion exchange membrane; MUF = UF permeate. Color version available online. 


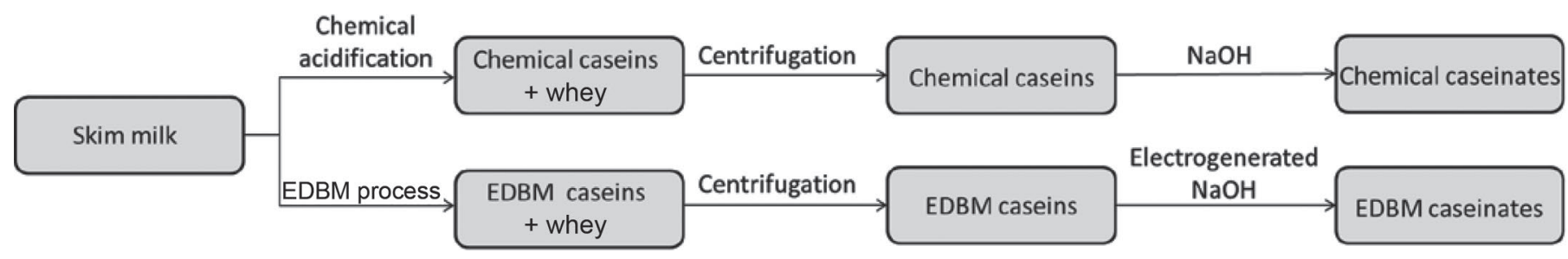

Figure 2. Production scheme of the electrodialysis with bipolar membrane (EDBM) process and the chemical process of caseins and caseinates from skim milk.

separate casein curd from whey. In parallel, a chemical acidification was done by decreasing the $\mathrm{pH}$ of $2 \mathrm{~L}$ of milk with $0.5 \mathrm{~N} \mathrm{HCl}$ (Carr and Golding, 2016) until pH reached 4.6 (casein isoelectric point) in a beaker under agitation. Total added $\mathrm{HCl}$ volume was noted. Two liters of acidified milk was then collected for centrifugation (Figure 2).

Casein separation was done by successive centrifugations (Avanti J-26 XP; Beckman Coulter, Brea, CA) for both processes. A first centrifugation at 11,000 $\times$ $g$ for 15 min and $4^{\circ} \mathrm{C}$ was carried out to separate the insoluble acid caseins from the liquid whey. The supernatant was then removed, and the remaining casein curd was washed with $1.8 \mathrm{~L}$ of distilled water. A second centrifugation with the same parameters was then carried out, followed by a second washing and a third centrifugation. Samples from the supernatants were collected after each centrifugation. The final casein curd was split into 2 equal parts; one was lyophilized for $72 \mathrm{~h}$, and the other underwent a basification and solubilization step to produce caseinates (Figure 2).

This basification was done with a $0.5 \mathrm{~N} \mathrm{NaOH}$ solution for the chemical process, and the $\mathrm{NaOH}$ produced in the second EDBM compartment was used for the electrodialytic method. The $\mathrm{NaOH}$ produced in the EDBM stack was titrated with a $0.5 \mathrm{~N} \mathrm{HCl}$ solution using a phenolphthalein indicator to determine its concentration. The $\mathrm{NaOH}$ solution was progressively added to the acid casein curd under constant agitation on a laboratory stirrer and hot plate (model PC-420; Corning, New York, NY) with a magnetic stirrer (speed 5) at a temperature of 70 to $75^{\circ} \mathrm{C}$ until a pH of 6.7 to 6.8 was reached and the complete dissolution of the caseins was observed. A temperature of 70 to $75^{\circ} \mathrm{C}$ was used to facilitate solubilization of caseins during $\mathrm{NaOH}$ addition. As reported by Carr and Golding (2016), a localized viscous layer tends to appear on the surface of the casein particles, preventing sodium hydroxide action; hence, an increase in temperature reduced this problem. The volume of $\mathrm{NaOH}$ added was noted. The alkalinized casein fraction (caseinate) was then lyophilized for $72 \mathrm{~h}$. Both lyophilized acid casein and casein- ate fractions obtained from the chemical and electrodialytic methods were collected to determine their ash, moisture, protein, and lactose contents and to analyze their mineral composition.

\section{Analyses}

Theoretical Casein Mass in Milk. Theoretical mass of caseins in milk was calculated using values from Miller et al. (2000). The following formula was used:

(Theoretical g of protein in skim milk/

L of skim milk) $\times$ Theoretical ratio of casein

to total skim milk protein $\times$ L of skim milk used $=$

Theoretical casein mass in skim milk.

Titration of Base Produced by EDBM. The titration of produced $\mathrm{NaOH}$ in the second compartment of EDBM was carried out using a $0.5 \mathrm{~N} \mathrm{HCl}$ solution with a phenolphthalein indicator. The $\mathrm{HCl}$ was gradually added using a burette to $10 \mathrm{~mL}$ of the base solution until color change. The result was expressed as milliliters of $\mathrm{HCl}$ per liter.

Quantity of $\mathrm{H}^{+}$and $\mathrm{OH}^{-}$Used for Casein and Caseinate Production. The theoretical concentration of $\mathrm{H}^{+}$and $\mathrm{OH}^{-}$produced by EDBM was calculated by Faraday's law for electrolysis, $n=\frac{I \times t}{F}$, where $n$ is the number of moles produced, $I$ is the current applied, $t$ is the time in seconds, and $F$ is the Faraday constant. In addition, a conservative current efficiency of $75 \%$ was used. Typical values of current efficiency for laboratory scale electrodialysis cells are about 75 to $90 \%$ (Leiva, 1988; Mafart and Béliard, 1992; Kaveh et al., 2009).

The $\mathrm{H}^{+}$needed for casein production were calculated by comparing the number of moles of $\mathrm{H}^{+}$added to the milk (chemically or electrochemically) to the theoretical amount of casein contained in milk calculated as previously from Miller et al. (2000). The $\mathrm{OH}^{-}$needed for 
soluble caseinate production (by basification of caseins) was found by calculating total moles of $\mathrm{OH}^{-}$from $\mathrm{NaOH}$ volume added to the lyophilized caseins powder separated previously from milk. For electrochemical acidification, the theoretical value for $\mathrm{OH}^{-}$was calculated by Faraday's law but also compared with the value obtained for the base titration using phenolphthalein.

Ash Content. Ash content of the lyophilized samples of caseins and caseinates obtained after centrifugation of acidified skim milk was determined using the modified AOAC method 945.46 (AOAC International, 2006). Crucibles were soaked in a solution of $5 \% \mathrm{HNO}_{3}$ for $1 \mathrm{~h}$ to solubilize residual ashes that could be present in the crucibles. Crucibles were then washed with ultrapure water and conditioned at $550^{\circ} \mathrm{C}$ in an oven for $18 \mathrm{~h}$ to remove volatile compounds and obtain an accurate mass measurement. The crucible's mass was then noted. About $1 \mathrm{~g}$ of sample was added to each crucible before placing it in a stove at $105^{\circ} \mathrm{C}$ for 24 $\mathrm{h}$. The sample-containing crucible was then incinerated at $550^{\circ} \mathrm{C}$ for $18 \mathrm{~h}$. The crucible's mass with sample before and after incineration was noted to acquire the ash content according to the following equation, where $\mathrm{CrM}=$ crucible mass:

$$
\begin{aligned}
& \% \text { ash }= \\
& \frac{\text { CrM with sample after incineration }-\mathrm{CrM}}{\text { CrM with sample before incineration }-\mathrm{CrM}} \times 100 \text {. }
\end{aligned}
$$

Moisture Content. Moisture content of the lyophilized caseins and caseinates was determined by placing $1 \mathrm{~g}$ of sample in an aluminum cup in a $105^{\circ} \mathrm{C}$ stove for $36 \mathrm{~h}$ to evaporate the water in the sample. Mass of cups and mass before and after evaporation of the samples were noted to acquire the moisture content according to the following equation, where $\mathrm{CM}=$ cup mass:

$$
\begin{aligned}
& \% \text { moisture }= \\
& \left(1-\frac{\mathrm{CM} \text { with sample after drying }-\mathrm{CM}}{\mathrm{CM} \text { with sample before drying }-\mathrm{CM}}\right) \times 100 .
\end{aligned}
$$

Protein Content. Protein content of the lyophilized casein and caseinate samples was determined using a Leco Truspec device (Leco Corp., Saint Joseph, MI). This device uses the Dumas combustion method, which consists of transforming organic nitrogen to molecular nitrogen and routing it to a detector (method 14891, ISO, 2002). Parameters used were a furnace temperature of $950^{\circ} \mathrm{C}$, a postcombustion temperature of $850^{\circ} \mathrm{C}$, incineration steps of $90 \mathrm{~s}$ with a high furnace flow, and gas purity of $99.993 \%$ for helium and $99.995 \%$ for oxygen. Nitrogen conversion factor was 6.38 (IDF, 2016).
Lactose Content. Lactose content was determined by HPLC method. Liquid samples were diluted and then placed in the HPLC device (Waters Corp., Milford, MA) with an ICSep-ION-300 column (Tansgenomic, Omaha, NE). A refractive index detector (Hitachi, Foster City, CA) was used to quantify lactose. For caseins, a dilution step was performed as well as a resolubilization step using $0.5 \mathrm{~N} \mathrm{NaOH}$ until pH 6.7; a filtration step using $0.45-\mu \mathrm{m}$-pore filters was then made before passing the solubilized caseins into the HPLC. Lyophilized caseinate samples were solubilized in water and then diluted before passing them in HPLC.

Mineral Composition. Mineral composition of caseins and caseinates was determined using the ash samples obtained during the ash determination step. These ashes samples were solubilized in $25 \% \mathrm{HNO}_{3}$ for 1 $\mathrm{h}$ and then diluted and filtered with $0.2-\mu \mathrm{m}$-pore filters before being analyzed by optical emission spectrometry with inductively coupled plasma ionization (Optima 4300, Dual View, Perkin-Elmer, Waltham, MA). The wavelengths used were $285.219,317.933,589.592$, and $766.490 \mathrm{~nm}$ for magnesium, calcium, sodium, and potassium, respectively. These cation analyses were carried out in radial view.

\section{RESULTS AND DISCUSSION}

\section{Milk pH Evolution During EDBM Process}

Milk $\mathrm{pH}$ decreased from an initial $\mathrm{pH}$ of about 6.7 to a final $\mathrm{pH}$ of 4.8 throughout the EDBM process (Figure 3 ) by $\mathrm{H}^{+}$electrogenerated on the cationic side of the BPM adjacent to the MUF compartment. The slow acidification was due to the buffer capacity of milk (e.g., proteins, weak acids) and the release of phosphate anions from the caseins, neutralizing the acidification effect of the $\mathrm{H}^{+}$addition (Buchanan and Peterson, 1927). As $\mathrm{pH}$ decreased, protein-bound compounds of calcium (or magnesium) phosphates (or citrates) converted to the soluble ionic form and remained in the whey fraction (Lucey and Horne, 2009). The phosphorcontaining anions along with citrate anions consumed a part of the $\mathrm{H}^{+}$produced by the BPM, decreasing the rate of acidification. Milk $\mathrm{pH}$ decreased in a similar way to the one observed previously by Bazinet et al. (2000b).

\section{Milk Conductivity Evolution During EDBM Process}

Conductivity of milk decreased throughout the EDBM process (Figure 3). As the EDBM process progressed, cations present in the MUF were transported to the adjacent concentrate compartment (compart- 
ment 4), being attracted by the cathode. This migration of cations from milk to the adjacent compartment through the cation exchange membrane was responsible for the decrease in conductivity over time (Bazinet et al., 2000a). The nonlinear nature of the curve was attributed to the release of cations and anions bound to caseins micelles (mostly colloidal tricalcium phosphate) into the soluble whey phase (Bazinet et al., 2000a). This increase of soluble ionic content in the MUF would have then increased its conductivity and then partially counteracted the inherent demineralization effect of the EDBM configuration through the CEM. Milk conductivity decreased in a way similar to Bazinet et al. (2000a).

\section{Relative $\boldsymbol{H}^{+}$Addition to Produce Insoluble Acidified Caseins}

It was found that the EDBM process necessitated less $\mathrm{H}^{+}$than the chemical process, with values of $0.00124 \pm 0.00010$ compared with $0.00194 \pm 0.00005$ $\mathrm{mol} / \mathrm{g}$ of caseins $(P<0.0002)$. The higher value for the chemical process was due to the fact that casein precipitation was carried out at a lower $\mathrm{pH}$ in comparison with the EDBM process (4.6 compared with 4.8 ), which consequently increased the number of $\mathrm{H}^{+}$required for acidification.
These values are lower than the ones obtained by Whittier (1929), who obtained an adjusted value of $0.00280 \mathrm{~mol} / \mathrm{g}$ of caseins. This difference was probably caused by the fact that the acidification of milk was made from $\mathrm{pH} 7.0$ to $\mathrm{pH} 4.0$, a higher $\mathrm{pH}$ range than the one used in this study, thereby necessitating higher quantities of acid to decrease $\mathrm{pH}$. In addition, the milk composition may vary according to the cow breed, diet, lactation period, and season (White and Davies, 1958).

\section{Relative $\mathrm{OH}^{-}$Addition to Produce Soluble Basified Caseinates}

Following caseins extraction, $\mathrm{OH}^{-}$additions to produce caseinates from both processes were calculated. The $\mathrm{NaOH}$ generated by the electrochemical process was titrated and presented a titration value of $0.212 \pm$ $0.001 \mathrm{~mol} / \mathrm{L}$. Both processes needed a similar quantity of $\mathrm{NaOH}$ to produce caseinates, with values of 0.00070 $\pm 0.00002 \mathrm{~mol} / \mathrm{g}$ of caseins for the EDBM process and $0.00073 \pm 0.00002 \mathrm{~mol} / \mathrm{g}$ of caseins for the chemical process $(P>0.05)$. This result was unexpected because the final EDBM pH was lowered to 4.8 instead of the standard 4.6 for the chemical process: consequently, fewer $\mathrm{OH}^{-}$ions would have been needed to reach the final $\mathrm{pH}$ of 6.7 to 6.8 in the basification step.

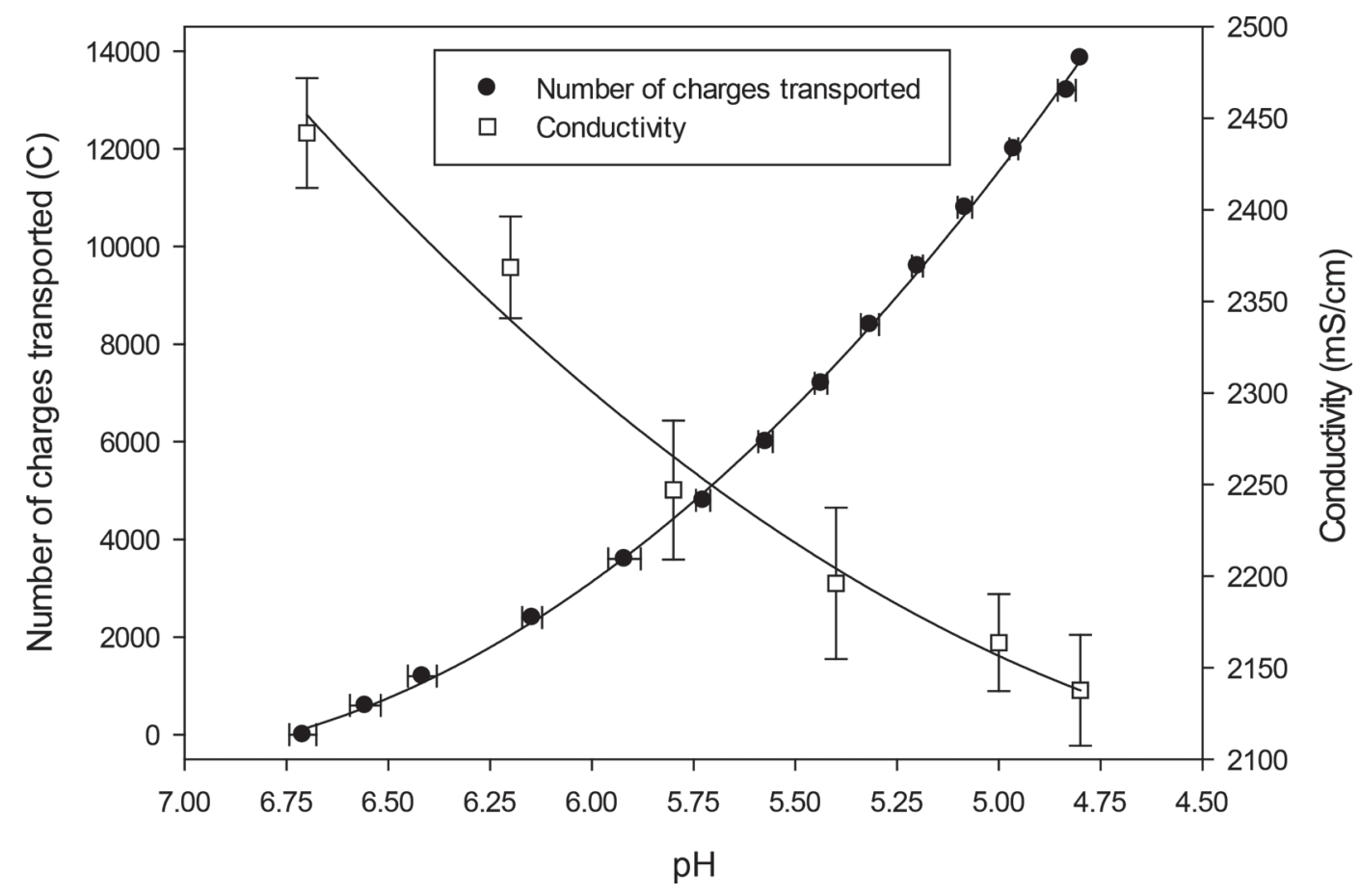

Figure 3. Milk pH and conductivity evolutions during the electrodialysis with bipolar membrane (EDBM) process. Error bars represent SD. 


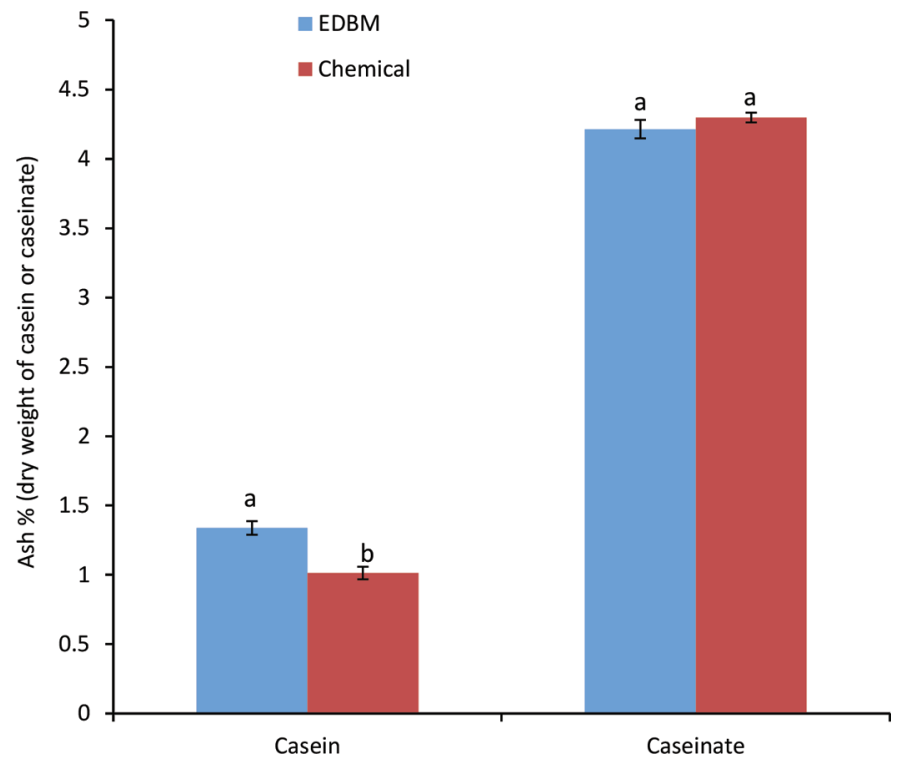

Figure 4. Ash content of caseins and caseinates from the electrodialysis with bipolar membrane (EDBM) and chemical acidification processes. The error bar represents SD, and data with different letters (a,b) are significantly different at $P<0.05$. Color version available online.

The $\mathrm{NaOH}$ addition requirements were found to be higher in the present study compared with the value of $0.00058 \mathrm{~mol} / \mathrm{g}$ of caseins obtained by Zittle et al. (1959). This difference of values could probably be attributed to the different conditions of basification used (e.g., temperature, $\mathrm{pH}$, particle size; Carr and Golding, 2016)

\section{Mineral Composition}

Following electrodialysis, it was found that the caseins obtained had a higher ash content than those from the conventional chemical acidification, with a value of $1.34 \pm 0.05 \%$ compared with $1.01 \pm 0.05 \%$ ( $P$ $<0.005$; Figure 4$)$. The higher ash content value could be attributed to the different final $\mathrm{pH}$ between both processes, as the complete precipitation of caseins was obtained at $\mathrm{pH} 4.8$ from the EDBM process compared with the standard $\mathrm{pH} 4.6$ in the chemical process.

These ash content values are quite similar to the ones obtained by Bazinet et al. (2000b), with values of $1.20 \%$ for the EDBM process and $1.28 \%$ for the chemical process. The small difference in ash content could be attributed to the different centrifugation methods, as Bazinet et al. (2000b) used a centrifugation step at $500 \times g$ for 10 min compared with the $11,000 \times g$ for $15 \mathrm{~min}$ in the present study. This variable could have influenced ash retention. Of interest is that the higher final $\mathrm{pH}$ would have allowed a greater quantity of divalent cations $\left(\mathrm{Ca}^{2+}, \mathrm{Mg}^{2+}\right)$ to remain in the casein matrix by being bound to phosphoserine residues (Le Graet and Brulé, 1993).

Ash content for caseinates was unsurprinsingly higher than for caseins due to the increased amount of $\mathrm{Na}^{+}$ from the addition of $\mathrm{NaOH}$ to caseins, with values of $4.21 \pm 0.04 \%$ for the EDBM process and $4.30 \pm 0.07 \%$ for the chemical process (Figure 4). These caseinate ash content values were nevertheless not significantly different between both processes $(P>0.05)$. These similar values, in contrast to the different ash values of caseins from both methods, were due to the slightly higher quantity of $\mathrm{NaOH}$ added in the case of chemically produced caseinates. Indeed, as the final $\mathrm{pH}$ for casein production was 4.6 compared with 4.8 for the EDBM process, a higher quantity of $\mathrm{NaOH}$ was added to the chemically produced caseins for soluble caseinate production at a $\mathrm{pH}$ of 6.7 to 6.8. These ash contents were similar to the ash content observed in standard caseinates of $3.98 \%$ of ash on a dry basis $(3.8 \%$ wet basis; Huffman and Harper, 1999).

\section{Mineral Characterization}

The calcium and magnesium contents were higher for caseins produced by the EDBM process than for those produced by the chemical process, with values of 0.22 $\pm 0.02 \%$ compared with $0.057 \pm 0.004 \%$ for calcium (about 4 times higher; $P<0.001$ ) and $0.011 \pm 0.0002 \%$ compared with $0.0032 \pm 0.0008$ for magnesium (about 4 times higher; $P<0.001$; Figure 5). As stated previously, these results are due to the higher final $\mathrm{pH}$ of EDBM, inducing a lower solubilization of $\mathrm{Ca}^{2+}$ and $\mathrm{Mg}^{2+}$ from the caseins. Indeed, those minerals are bound to the phosphoserine groups of different individual caseins and remain as colloidal phosphocalcic (phosphomagnesic) bridges inside the casein micelles and are released as pH decreases (Le Graet and Brulé, 1993). As the proportion of bound calcium and magnesium decreases in favor of the soluble form as the $\mathrm{pH}$ decreases, a higher proportion of those minerals was extracted from the casein curd in the centrifugation step of production, consequently reducing their contents in the final casein fraction. Sodium and potassium contents were found to be not significantly different between both processes. Sodium values were $0.59 \pm 0.04 \%$ for EDBM and 0.47 $\pm 0.06 \%$ for the chemical process $(P>0.05)$, whereas values for potassium were $0.13 \pm 0.004 \%$ for the EDBM process and $0.10 \pm 0.02 \%$ for the chemical process $(P$ $>0.05$; Figure 5 ). These results are probably due to the fact that sodium and potassium are mostly present in unbound form in caseins, each being present in the colloidal bound form at only 8\% (Le Graet and Brulé, 


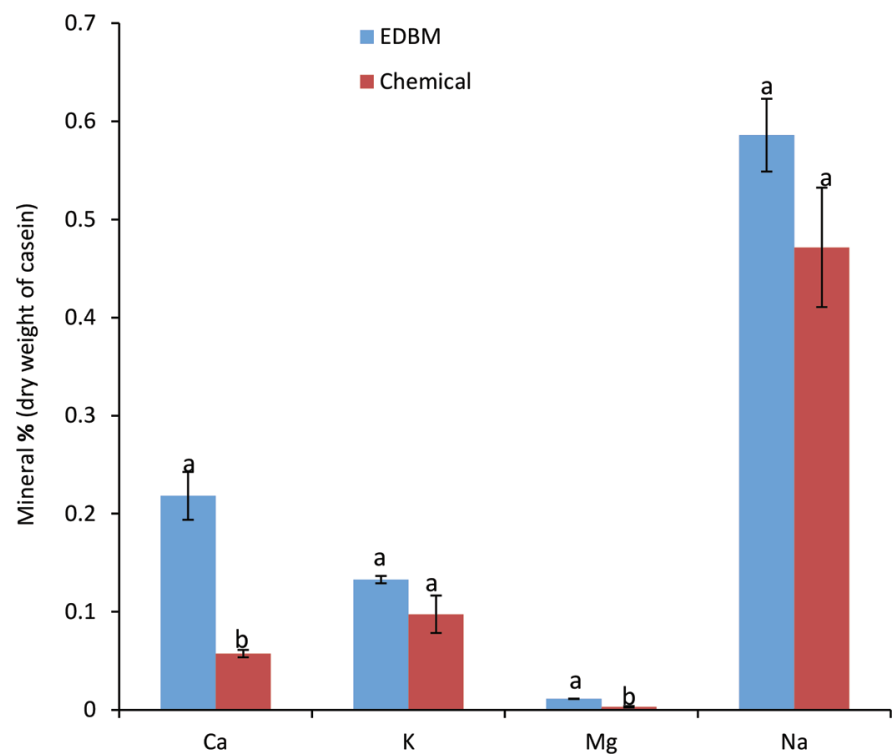

Figure 5. Mineral composition of caseins from the electrodialysis with bipolar membrane (EDBM) and chemical acidification processes. The error bar represents SD, and data with different letters $(a, b)$ are significantly different at $P<0.05$. Color version available online.

1993). These minerals are easily rejected from caseins toward the whey in the centrifugation step of production.

Calcium and magnesium contents from chemically acidified caseins were found to be somewhat similar to those of Noël et al. (2008), who obtained values of 0.0382 and $0.0054 \%$, respectively, whereas sodium and potassium contents were found to be much lower, with values of $0.0040 \%$ for sodium and $0.0026 \%$ for potassium. These different values are attributable to the centrifugation procedures used in both studies having the potential of increasing or decreasing the final soluble mineral retention.

Similar trends were found for caseinates (Figure 6). Calcium and magnesium contents were found to be greatly higher following the EDBM process compared with the standard chemical process, with values of 0.18 $\pm 0.005 \%$ compared with $0.062 \pm 0.02 \%$ for calcium (about 3 times more; $P<0.005$ ) and $0.010 \pm 0.001 \%$ compared with $0.0036 \pm 0.001 \%$ for magnesium (about 3 times more; $P<0.005$; Figure 6 ). Once again, the presence of more calcium and magnesium in caseinates was due to the fact that they were more present in bound form. Because no calcium or magnesium were added or removed following the basification step of caseinate production from caseins, their values were similar before and after conversion. Sodium content was lower for the EDBM process than for the chemical process, with values of $2.3 \pm 0.02 \%$ compared with 2.6 $\pm 0.1 \%(P<0.05$; Figure 6$)$. The lower value for the
EDBM process, as explained previously, was attributed to the fact that slightly less $\mathrm{NaOH}$ was added to the caseins for this treatment compared with the chemical process for caseinate production. Sodium content was higher for caseinates compared with caseins because a high $\mathrm{Na}^{+}$ion content was added in the form of $\mathrm{NaOH}$ to convert the acid-insoluble caseins to soluble caseinates. Potassium contents were not found to be different between the treatments, with values of $0.16 \pm 0.02 \%$ for the EDBM process and $0.13 \pm 0.002 \%$ for the chemical process $(P>0.05$; Figure 6$)$. This result can be attributed to the fact that most of the potassium in caseins is found in soluble form, which is easily withdrawn from the caseins curd into the whey during centrifugation. As expected, potassium content in caseinates was similar to potassium content in caseins considering that no potassium ions were added or removed in the basification process to produce caseinates.

Calcium content was found to be somewhat similar to the standard content for chemically produced caseinates of $0.03 \%$ (Huffman and Harper, 1999), whereas the sodium content in the present study was lower than that in the work of Huffman and Harper (1999), with values of $1.2 \%$. Differences in ash content could be attributed to an excess of $\mathrm{NaOH}$ that could have been added to produce the caseinates in the present study, as $\mathrm{NaOH}$ addition was performed until a $\mathrm{pH}$ of 6.7 to 6.8. This difference in final $\mathrm{pH}$ could bring variation in the final ash content. Concerning magnesium and

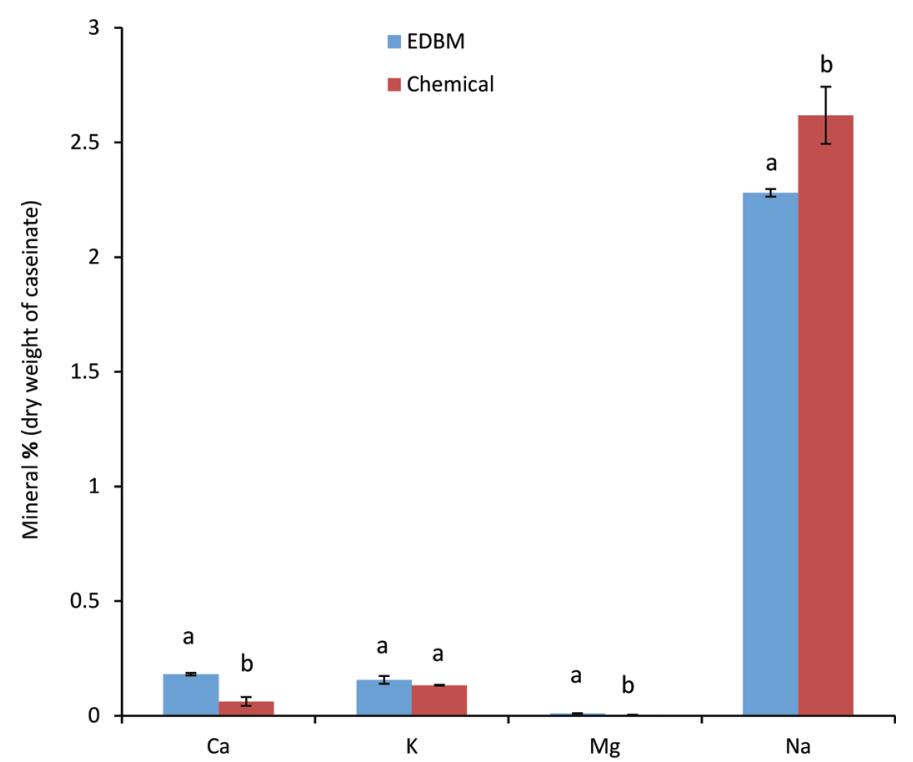

Figure 6. Mineral composition of caseinates from the electrodialysis with bipolar membrane (EDBM) and chemical acidification processes. The error bar represents SD, and data with different letters $(\mathrm{a}, \mathrm{b})$ are significantly different at $P<0.05$. Color version available online. 
potassium, their standard content values in caseinates were not found in the literature.

\section{Lactose Content}

Lactose content of caseins from both processes was similar, with values of $0.25 \pm 0.06 \%$ for EDBM and 0.18 $\pm 0.01 \%$ for the chemical process $(P>0.05$; Figure 7$)$. Because no lactose removal steps were applied in either process, these similar results were expected. For the same reasons, similar lactose contents were found in caseinates, with $0.18 \pm 0.03 \%$ for EDBM and $0.19 \pm$ $0.05 \%$ for the chemical process $(P>0.05$; Figure 7$)$.

The standard lactose concentration for caseins and caseinates is $0.1 \%$ (Huffman and Harper, 1999), which is lower than the one found in this study. These results could be attributed to standard lactose variation in cow milk or differing centrifugation steps, which would influence lactose retention in the casein curd.

\section{Protein Concentration}

The protein concentration in chemically produced caseins was higher than the caseins produced by the EDBM process, with respective values of $96.3 \pm 0.3 \%$ and $95.3 \pm 0.5 \%(P<0.005 ;$ Figure 8$)$. This difference was attributable to the higher ash content obtained in the EDBM-produced caseins, consequently reducing the overall protein content of the product. These results for casein protein content are somewhat similar to the

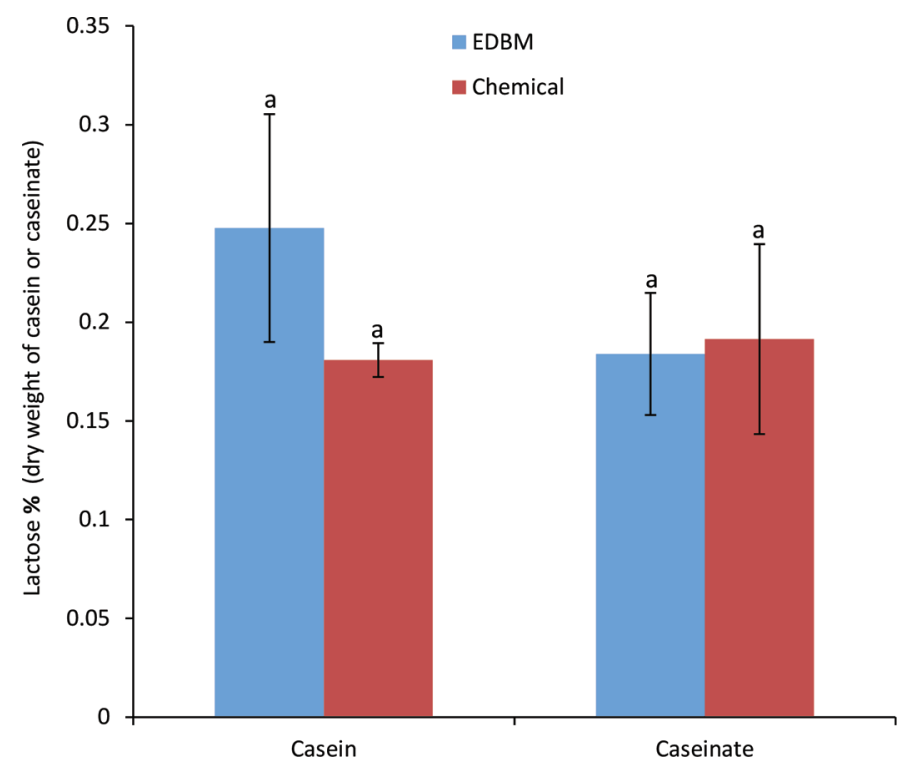

Figure 7. Lactose content of caseins and caseinates from the electrodialysis with bipolar membrane (EDBM) and chemical acidification processes. The error bar represents SD, and data with different letters are significantly different at $P<0.05$. Color version available online.

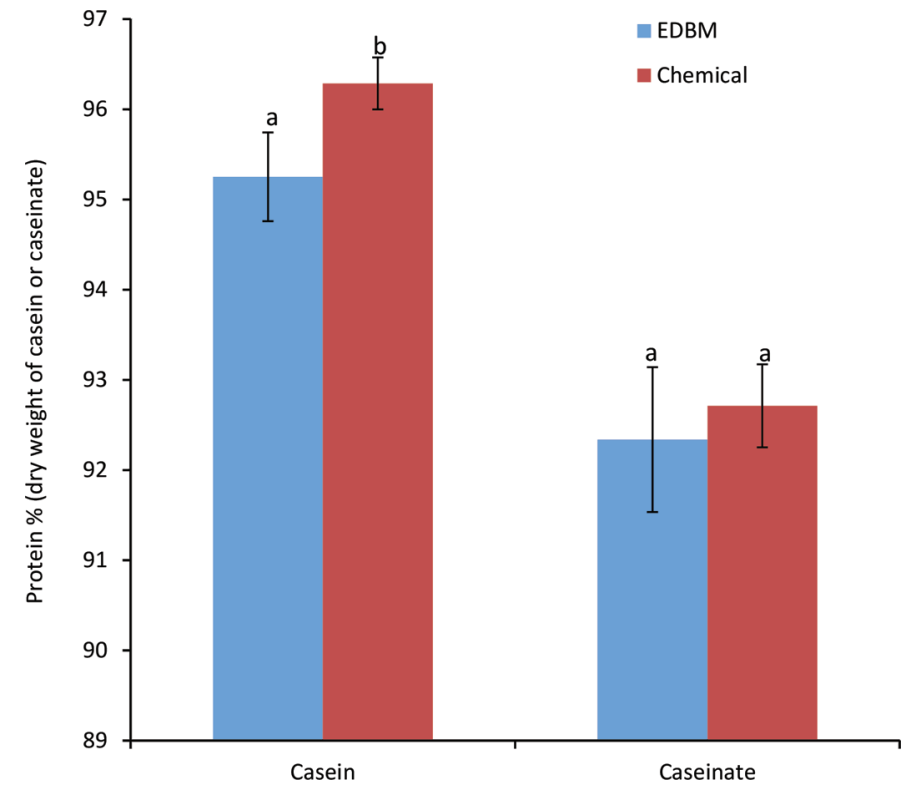

Figure 8. Protein content of caseins and caseinates from the electrodialysis with bipolar membrane (EDBM) and chemical acidification processes. The error bar represents SD, and data with different letters $(\mathrm{a}, \mathrm{b})$ are significantly different at $P<0.05$. Color version available online.

Huffman and Harper (1999) results of $96.6 \%(87.3 \%$ wet basis).

The protein contents of caseinates were unsurprisingly lower than for caseins due to the addition of ash content from $\mathrm{NaOH}$. Nevertheless, protein concentration was found to be the same for both processes, with a value of $92.3 \pm 0.8 \%$ and $92.7 \pm 0.5 \%$ for the EDBM and chemical processes, respectively $(P>0.05$; Figure $8)$. The difference in protein content in caseins due to the presence of more calcium and magnesium was, however, masked by the high quantity of sodium added, leading to no difference in ash content between caseinates. These values are similar to the standard caseinate protein content of $94.8 \%$ (90.4\% wet basis) obtained by Huffman and Harper (1999).

The results obtained also show that the caseins and caseinates produced by EDBM were equivalent in terms of lactose and protein contents to their respective chemically produced caseins and caseinates but presented lower sodium content and higher magnesium and calcium contents. The higher calcium content and, to a lesser extent, magnesium content are very interesting because these high concentrations induced by the new EDBM process add increased value to the final product. Indeed, the high calcium content of the produced caseins and caseinates could justify their use as a calcium-rich protein source, notably in osteoporosis patients, because calcium is essential to bone health (Heaney, 2000). Furthermore, the fact that the calcium 
is likely bound to milk protein makes it somewhat $\mathrm{pH}$ resistant and ensured its absorbability (Guéguen and Pointillart, 2000). This could make these caseins or caseinates from the new EDBM process suitable as an improved protein-based calcium supplement both for its enhanced nutritional quality and for the fact that it is produced by a green process. The reduced sodium content of caseinates from the EDBM process (around $12 \%$ ) is also interesting because higher sodium contents in food can lead to high blood pressure, bringing different health issues (Havas et al., 2007). Furthermore, the new food policies tend to decrease the sodium content in food. All these characteristics give the EDBM caseins and caseinates enhanced nutritional qualities. In addition, a recent life cycle analysis considering both processes demonstrated that the EDBM was more environmentally friendly than the standard chemical acidification-basification (Mikhaylin et al., 2018). Further research will aim to evaluate the possibility of adding a diafiltration step to reduce lactose content in the different protein isolates, which would increase their purity.

\section{CONCLUSIONS}

The results obtained in this study show for the first time that caseinates can be produced by solubilizing produced caseins with recycled $\mathrm{NaOH}$ stream from the EDBM process. This could lead to a process that produces caseins and caseinates with high calcium content and a whey by-product with low lactose content. In addition, research on functional and nutritional properties of the EDBM-produced caseinates will be carried out.

\section{ACKNOWLEDGMENTS}

The financial support of the Natural Sciences and Engineering Research Council of Canada (NSERC; Ottawa, ON, Canada) is acknowledged. This work was supported by the NSERC Industrial Research Chair on electromembrane processes aiming for the ecoefficiency improvement of biofood production lines (grant IRCPJ 492889-15 to Laurent Bazinet) and the NSERC Discovery Grants Program (grant RGPIN-2018-04128 to Laurent Bazinet).

\section{REFERENCES}

AOAC International. 2006. Official Methods of Analysis. Proximate Analysis and Calculations Ash Determination (Ash) Milk - Item 53. Method 945.46. 17th ed. AOAC International, Gaithersburg, MD.

Augustin, M. A., C. M. Oliver, and Y. Hemar. 2011. Casein, caseinates, and milk protein concentrates. Pages $161-178$ in Dairy Ingredients for Food Processing. R. C. Chandan and A. Kilara, ed. Wiley-Blackwell, Hoboken, NJ.
Bazinet, L., D. Ippersiel, D. Montpetit, B. Mahdavi, J. Amiot, and F. Lamarche. 2000a. Effect of membrane permselectivity on the fouling of cationic membranes during skim milk electroacidification. J. Membr. Sci. 174:97-110. https://doi.org/10.1016/s0376 $-7388(00) 00379-3$

Bazinet, L., F. Lamarche, D. Ippersiel, and J. Amiot. 1999. Bipolar membrane electroacidification to produce bovine milk casein isolate. J. Agric. Food Chem. 47:5291-5296. https://doi.org/10.1021/ jf990524m.

Bazinet, L., F. Lamarche, D. Ippersiel, C. Gendron, B. Mahdavi, and J. Amiot. 2000b. Comparison of electrochemical and chemical acidification of skim milk. J. Food Sci. 65:1303-1307. https://doi .org/10.1111/j.1365-2621.2000.tb10601.x.

Bazinet, L., D. Montpetit, D. Ippersiel, J. Amiot, and F. Lamarche. 2001. Identification of skim milk electroacidification fouling: A microscopic approach. J. Colloid Interface Sci. 237:62-69. https://doi .org/10.1006/jcis.2001.7439.

Buchanan, J. H., and E. E. Peterson. 1927. Buffers of milk and buffer values. J. Dairy Sci. 10:224-231. https://doi.org/10.3168/jds .S0022-0302(27)93836-3.

Cao, Y., and D. Li. 2013. Impact of increased demand for animal protein products in Asian countries: Implications on global food security. Anim. Front. 3:48-55. https://doi.org/10.2527/af.2013-0024.

Carr, A., and M. Golding. 2016. Functional milk proteins production and utilization: Casein-based ingredients. Adv. Dairy Chem. 1B:35-66. https://doi.org/10.1007/978-1-4939-2800-2_2.

Elliot, T. A., M. G. Cree, A. P. Sanford, R. R. Wolfe, and K. D. Tipton. 2006. Milk ingestion stimulates net muscle protein synthesis following resistance exercise. Med. Sci. Sports Exerc. 38:667-674. https://doi.org/10.1249/01.mss.0000210190.64458.25.

Guéguen, L., and A. Pointillart. 2000. The bioavailability of dietary calcium. J. Am. Coll. Nutr. 19:119S-136S.

Havas, S., B. D. Dickinson, and M. Wilson. 2007. The urgent need to reduce sodium consumption. JAMA 298:1439-1441. https://doi .org/10.1001/jama.298.12.1439.

Heaney, R. P. 2000. Calcium, dairy products and osteoporosis. J. Am. Coll. Nutr. 19:83S-99S. https://doi.org/10.1080/07315724.2000 .10718088 .

Huffman, L. M., and W. J. Harper. 1999. Maximizing the value of milk through separation technologies. J. Dairy Sci. 82:2238-2244. https://doi.org/10.3168/jds.S0022-0302(99)75471-8.

IDF (International Dairy Federation). 2016. Evaluation of the nitrogen conversion factors for dairy and soy. Bulletin no. 482. IDF, Schaerbeek, Belgium.

International Organization for Standardization (ISO). 2002. Method ISO 14891:2002 (IDF 185:2002) Milk and milk products-Determination of nitrogen content-Routine method using combustion according to the Dumas principle. ISO, Geneva, Switzerland.

Kaveh, N. S., F. Mohammadi, and S. N. Ashrafizadeh. 2009. Prediction of cell voltage and current efficiency in a lab scale chlor-alkali membrane cell based on support vector machines. Chem. Eng. J. 147:161-172. https://doi.org/10.1016/j.cej.2008.06.030.

Korhonen, H., and A. Pihlanto. 2006. Bioactive peptides: Production and functionality. Int. Dairy J. 16:945-960. https://doi.org/10 .1016/j.idairyj.2005.10.015.

Le Graet, Y., and G. Brulé. 1993. Les équilibres minéraux du lait: Influence du $\mathrm{pH}$ et de la force ionique. Lait 73:51-60. https://doi .org/10.1051/lait:199312.

Leiva, M. H. L. 1988. The use of electrodialysis in food-processing. 1. Some theoretical concepts. Lebensm. Wiss. Technol. 21:119-125.

Lucey, J. A., and D. S. Horne. 2009. Milk salts: Technological significance. Adv. Dairy Chem. 3:351-389. https://doi.org/10.1007/978 -0-387-84865-5_9.

Mafart, P., and E. Béliard. 1992. L'électrodialyse. Pages 185-208 in Génie Industriel Alimentaire: Tome II Techniques Séparatives. Techniques et Documentation Lavoisier, Paris, France.

MarketsandMarkets. 2014. Dairy ingredients market by type (milk powder, whey ingredients, lactose, MPC \& MPI, casein \& caseinates), by application (bakery \& confectionary, dairy, convenience foods, infant milk formula, sports \& clinical nutrition) - Global trends \& forecasts to 2018. Accessed Oct. 30, 2017. http://www 
.marketsandmarkets.com/Market-Reports/ dairy-ingredients-market-974.html.

Mikhaylin, S., M. Margni, L. Patoullard, and L. Bazinet. 2018. Bipolar membrane casein production using sustainable approach in electron dialysis coupled with ultrafiltration. Green Chem. 20:449-456.

Mikhaylin, S., V. Nikonenko, G. Pourcelly, and L. Bazinet. 2016. Hybrid bipolar membrane electrodialysis/ultrafiltration technology assisted by a pulsed electric field for casein production. Green Chem. 18:307-314. https://doi.org/10.1039/c5gc00970g.

Mikhaylin, S., and A. V. Sion. 2016. Improvement of a sustainable hybrid technology for caseins anisoelectric precipitation (electrodialysis with bipolar membrane/ultrafiltration) by mitigation of scaling on cation-exchange membrane. Innov. Food Sci. Emerg. Technol. 33:571-579. https://doi.org/10.1016/j.ifset.2015.11.026.

Miller, G. D., J. K. Jarvis, and L. D. McBean. 2000. Handbook of Dairy Foods and Nutrition. 2nd ed. Taylor and Francis, Boca Raton, FL.

Mounsey, J. S., B. T. O'Kennedy, and P. M. Kelly. 2005. Comparison of re-micellised casein prepared from acid casein with micellar casein prepared by membrane filtration. Lait 85:419-430.

Noël, L., M. Carl, C. Vastel, and T. Guerin. 2008. Determination of sodium, potassium, calcium and magnesium content in milk products by flame atomic absorption spectrometry (FAAS): A joint ISO/IDF collaborative study. Int. Dairy J. 18:899-904. https://doi .org/10.1016/j.idairyj.2008.01.003.
Singh, H. 2011, Functional properties of milk proteins. Pages 887-893 in Encyclopedia of Dairy Sciences. J. H. Fuquay, P. F. Fox, and P. L. H. McSweeney, ed. Academic Press, London, UK.

Tanaka, Y. 2010. Water dissociation reaction generated in an ion exchange membrane. J. Membr. Sci. 350:347-360. https://doi.org/10 .1016/j.memsci.2010.01.010.

Thorpe, M. P., E. H. Jacobson, D. K. Layman, X. M. He, P. M. KrisEtherton, and E. M. Evans. 2008. A diet high in protein, dairy, and calcium attenuates bone loss over twelve months of weight loss and maintenance relative to a conventional high-carbohydrate diet in adults. J. Nutr. 138:1096-1100.

White, J. C. D., and D. T. Davies. 1958. The relation between the chemical composition of milk and the stability of the caseinate complex. I. General introduction, description of samples, methods and composition. J. Dairy Res. 25:236-255. https://doi.org/10 $.1017 /$ S0022029900009249.

Whittier, E. O. 1929. Buffer intensities of milk and milk constituents. I. The buffer action of casein in milk. J. Biol. Chem. 83:79-88.

Zittle, C. A., E. S. Dellamonica, and L. Pepper. 1959. Casein and paracasein - Neutralization with alkali, precipitation by calcium chloride and binding of calcium. Arch. Biochem. Biophys. 81:187-193. https://doi.org/10.1016/0003-9861(59)90188-2. 